\title{
Poussin’s Kingdom of Flora: Love in the Garden
}

\author{
Lloyd James Bennett \\ Thompson Rivers University, Kamloops, Canada
}

\begin{abstract}
The Fort Worth (Texas) exhibition/publication Poussin: The Early Years in Rome: The Origins of French Classicism (1988) proved to be a seminal event in Poussin scholarship. Over 200 works were put on display at the Kimbell Art Museum that revealed the formative years in the French painter's works. The drawings and paintings confirmed Poussin as the leading classicist in 17th century French art and expanded our appreciation of the flexibility of the artist to illustrate mythological narratives. Previous positions on the artist such as Anthony Blunt's, who viewed the painter as a strict classicist without a major interest in color, are now reevaluated after the Fort Worth show. The influence of the Venetian school, especially the work of Titian, emerged stronger into Poussin's oeuvre. It was under the classicist umbrella that the romantic verse of Ovid and the sensual color of Titian became forged into the pictures of Roman mythology. The leading source of inspiration for this work would be Ovid's Metamorphoses where figures change into flowers made timeless by the painter's brush. Just as the poet varied the structure of his narrative presentation, so too did the painter expand his approach to depicting scenes of change in a variety of formats. A key work for Poussin in these stories of change would be the Kingdom of Flora (1631) where Ovidian tales are posed as an eternal spring where the goddess distributes the flowers of the collective narrative in an olive green chitin. This paper will contribute to the position of viewing Poussin's art under a wider vision of classicism where flexible narrative design and sensuous color fit the mission to make art noble and timeless.
\end{abstract}

Keywords: Poussin, Ovid, painting, mythology, flowers, metamorphoses, 17th century

Spring I enjoy always, always the year is full of bloom, always the tree has leaves, the ground has fodder.

I have a fruitful garden in the fields that are my dowry; the breeze warms it, it's kept moist by a spring of clear water. This my husband has filled with noble flowers, and he says to me, "Goddess, have control of the flowers".

(Fasti, 2013, p. 92)

\section{Introduction}

When Nicholas Poussin arrived in Rome in the early 1620s he had already been introduced to mythological stories by the Italian poet Cavalier Marino (Friedlaender, 1960, pp. 13-15; Blunt, 1967, p. 39). In Rome Poussin pursued the subject with a set of drawings for Ovid's Metamorphoses (AD 1st-century), which set the painter's interest for the subject of mythological works. We know from biographer Giovanni Pietro Bellori that the young artist, while working in Paris, had become disillusioned with the dominant mannerist style that occupied Parisian artists and teachers (Bellori, 2010, p. 310). Bellori noted that Poussin's early interest in Rome lay with classical antique statues, the painter Domenichino and Titian's bacchanals in the Villa Ludovisi (Bellori, 2010, p. 311). This material, as well as prints after Raphael and Giulio Romano, which the

Lloyd James Bennett, associate professor, Department of Visual and Performing Arts, Thompson Rivers University. 
artist had seen in the Louvre, formed his early approach to classicizing his art or, as the biographer writes "imbibed the milk and essence of [his] art" (Bellori, 2010, p. 310). The mission to make antique stories eternal can be seen in his early Roman works such as the splendid Kingdom of Flora from 1631 where humans changed into flowers. ${ }^{1}$

\section{Flora's Kingdom}

The unique idea in the Kingdom of Flora is that the painting does not describe one story from Ovid's Metamorphoses but several fables. The idea of using multiple characters linked by a common theme first appears in Poussin's Triumph of Flora, c. 1628 (see Figure 1). Here the artist has Venus (Divine Love) lead a lively procession of Flora and her followers adorned with cupids and flowers. The perennials of the springtime garden are present in the lyrical procession: The legendary hero Ajax offers up on his shield of purple flowers (larkspur) to the radiant goddess atop her gold chariot; Venus' lover Adonis holds a basket of purple anemones, Narcissus has the white flowers of his namesake and Hyacinthus has his head wreathed in flowers. In the foreground of the picture, Clytie gathers the heliotrope, as her beloved Apollo (sun) is not visible in the cloud-filled sky, and the lovers Smilax and Crocus watch as the throng passes by (Bellori, 2010, pp. 325-326). Poussin's triumphant revelers are going to that place of eternal life controlled by the goddess of the springtime.

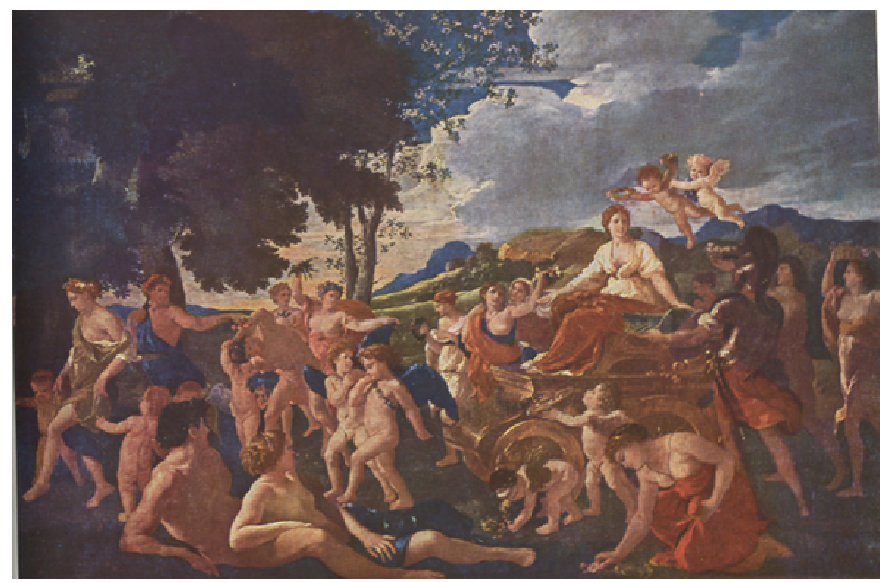

Figure 1. Nicholas Poussin, Triumph of Flora, c. 1627-28, Louvre, Paris.

Humans changing into flowers were but one of the themes of the Metamorphoses that Ovid reveals in his epic verse describing the origin and history of the world up to the poet's own Roman times. The first change we read about is how the cosmos was changed from chaos to order. After this followed the Golden Age where no law was required and no armies raised. Humans lived in peace before avarice appeared and mortals challenged the gods. Jove, who introduced the seasons and dished out punishment for those who challenged the throne of Heaven, ran this second period or Silver Age. Ovid's poem was to "tell of bodies changed to different forms" (Ovid, 1955, pp. 3-5) largely brought about by the relations among mortals and the gods and goddesses who

\footnotetext{
1 There has been disagreement on the title: Friedlander uses Realm of Flora, while Blunt and Konrad Oberhuber use Kingdom of Flora for the painting and drawings. See Poussin: The Early Years in Rome (New York: Hudson Hill Press, 1988), cat. Nos. 85 and D188; Christopher Wright uses Empire of Flora for the title of the painting. See Poussin Paintings: A Catalogue Raisonne (New York: Alpine Fine Arts Collection, 1984), p. 43 (62); Jane Costello, “The Twelve Pictures 'Ordered by Velasquez' and the Trial of Valguarnera”, Journal of the Warburg and Courtauld Institutes, Vol. XIII, 1950, p. 283. On 28 July 1631 Poussin was called to testify at the trial. The painting was commissioned by Vulguarnera in May, 1631 and called "the garden of flowers". See Friedlaender, p. 126.
} 
intervened in their affairs on earth. In those unhappy circumstances of love lost or early death the immortals would often mark the passing on earth with a colorful flower-a flower forever tended by the youthful goddess of the spring. ${ }^{2}$

\section{Flowers of Love and Honor}

Ovid described Flora's garden as a dowry gift from her husband Zephyrus where "the breeze warms it, it's kept moist by a spring of clear water” (Ovid, 2013, p. 92). Indeed Poussin's painting (see Figure 2) captured the idyllic setting where a garden expands below a cliff, marked by a term of Priapus, where a fountain drains into a pool surrounded on the south and west by a trellis through which a gentle breeze tickles golden leaves. Above the garden realm a range of cumulus clouds appears to support fair-skinned Apollo in his golden chariot pulled by four white horses. It is midday and the sun's radiance illuminates all of the semi-nude figures below in fixed poses like Greek statuary colored in places by wraps of drapery. And in the center of the garden before putto, Flora gaily sprinkles the flowers of spring in her gown of olive green.

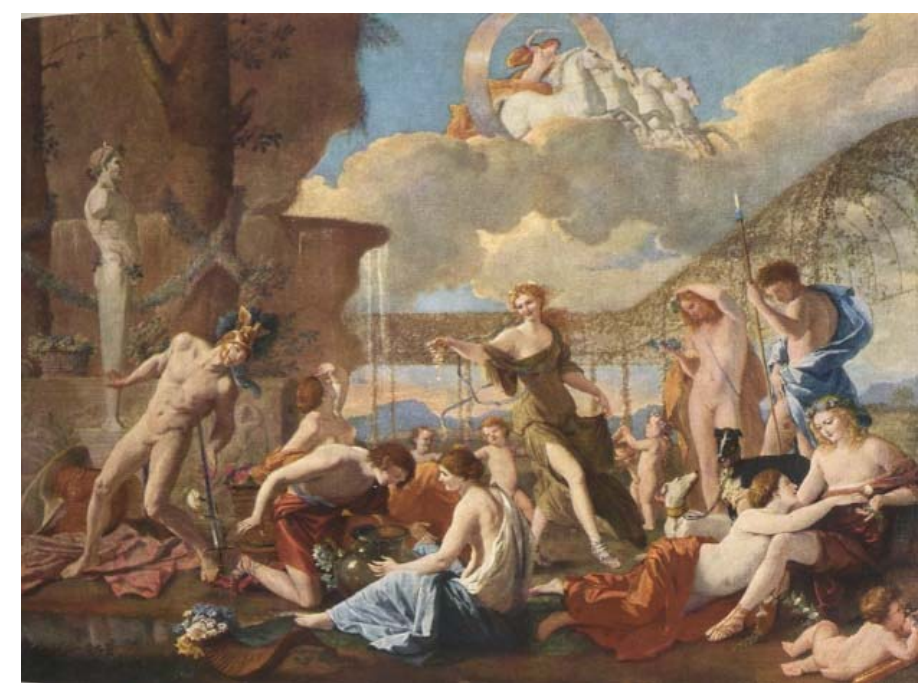

Figure 2. Nicholas Poussin, Kingdom of Flora, 1631, Staatliche Gemaldegalerie, Dresden.

These flowers formed crimson sprout forth from wounds or emerge marking sadly the death of a lover. Here disappointment and death are consoled by nature's regeneration of colorful plants. The deaths in the garden are displayed by the painter for best effect as in the suicide of Ajax where the Greek hero drives his sword "Deep in the breast which no man ever wounded". In his picture Poussin has standing Ajax fall on his sword from the side so that his naked boy, idealized in the classical style, may be viewed frontally where pectoral muscles are marked in shadow. Wearing only his golden helmet the hero holds a resolute gaze as he leans into the "deadly steel". ${ }^{3}$ Ovid indicates that the circumstance of the issuing blood producing a crimson flower like that which flowed from Hyacinthus' wound (an earlier tale) has petals inscribed with grieving words “Alas!” (Ovid, 1955, p. 240). The passage provides a history of transformation into the tall flower the color of blood, which Ovid has Flora introduce in the Fasti where the goddess says she was the "first to make a flower of Therapean blood—and the lament remains, written on its petal” (Ovid, 2013, p. 92). By bringing the

\footnotetext{
2 In the Fasti Ovid describes Flora’s mission to bring color to the earth by spreading flowers and to honor wounds. See p. 92.

3 Ovid, Metamorphoses, p. 318. The drawing for the painting indicates a more lateral gesture with the turning of the legs and position of the sword point.
} 
two stories together the poet brackets hero and youth at the Ajax suicide. Poussin reaches an equivalent honor in the Kingdom of Flora by having Ajax and Apollo bend toward each other in a bow of tribute from the sides of the painting.

Presentation for best effect marks the gestures and facial expression of the figures in metamorphosis. Moving from the tragedy of Ajax we come to the grouping of Narcissus and a nymph. Narcissus, who pined away unable to materialize his own reflection, looks into a water-filled urn (a picture within a picture) gesturing his confusion of not being able to love himself. Echo, who occupies much of the tale of self-love looks with concern over her unrequited lover's fate; she might be the nymph who holds the urn (although there are no attributes to this figure); Narcissus flowers are already falling from the urn and decorate the poolside in memory of the river-god's son who could love no woman. To make the story of unrequited love more poignant, Ovid relates Echo's fate (a story within a story) of how Juno, when looking for her husband, eventually figured out that the nymph was the lookout for Jove and punished her by having her repeat "the last thing she hears" (Ovid, 1955, p. 68). Fate would have Echo fall in love with Narcissus who could not follow her curious speech, even if he had not suffered from the curse of self-love. Poussin uses the urn to provide the reflection of self-love where the passions of no nymph could be fulfilled.

Another tale of the lover spurned follows beyond Narcissus in the Kingdom of Flora where Clytie shields her eyes from her beloved Apollo. Even after the sun god had scorned her love, she followed him across the Heaven and became rooted as a flower (heliotrope) turning "To the light of the sun” (Ovid, 1955, p. 89). The Clytie tale, like most of the stories of change, comes at the end of the narrative or resolution. Ovid had her demise come from staring at the sun god: "For nine whole days she sat there, with neither food nor drink, her hunger wanting nothing but dew and tears, unstirred and unstirring” (Ovid, 1955, pp. 89-90). Poussin, in contrast, has her in full health shading her gaze as she looked to the heavens from her position in Flora's garden.

For the tragic tales of Hyacinthus (on Flora's left) and Adonis, both standing, we witness the issuing forth of flowers from the wounds of these athletic figures. Apollo playing discuss with Hyacinthus caused the missile to hit the boy in the head bringing his early death. The Sun god laments the death of his friend and lays out the destiny of the crimson flower:

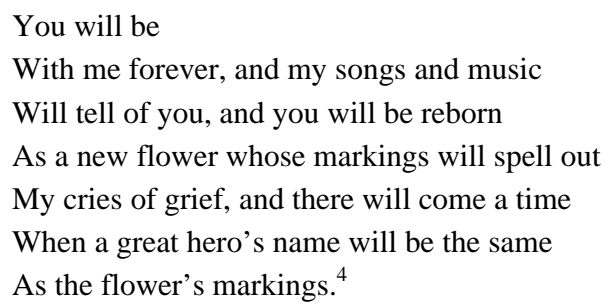

Adonis received the tribute from his lover Venus of the anemone from his leg wound caused by the boar while hunting. This crimson flower referenced the hunter's short life as "The wind-flower, shake the petals off, too early” (Ovid, 1955, p. 258). His hunting dogs tied together suggest a marital union that would not happen as

\footnotetext{
${ }^{4}$ Metamorphoses, p. 240. "An ancient Greek legend describes the origin of the Hyacinth. Two of the gods, Apollo and Zephyr, adored a handsome young Greek called Hyakinthos. Apollo was teaching Hyakinthos the art of throwing a discus. Zephyr, who was the god of the west wind, was overwhelmed with jealousy and he blew the discus back. It struck Hyakinthos on the head and killed him. From his blood grew a flower, which the sun god Apollo named after him". See "Hyacinth", http:www.theflowerexpert.com $(01,05,2014)$.
} 
the hunter chanced to hunt the wild beasts. Alas, the garden fills up with the flowers of early death, of love lost, marked forever in Flora's kingdom.

The last couple in the garden is the lovely Crocus and Smilax. Crocus is seated on the extreme right of the picture, above a Titianesque putto, and his lover the shepherdess Smilax, on the turf reclining, offers to her lover the white morning glory. The impatient lovers are only mentioned incidentally in the Metamorphoses as if the poet wanted to get onto bigger stories of figures changing.

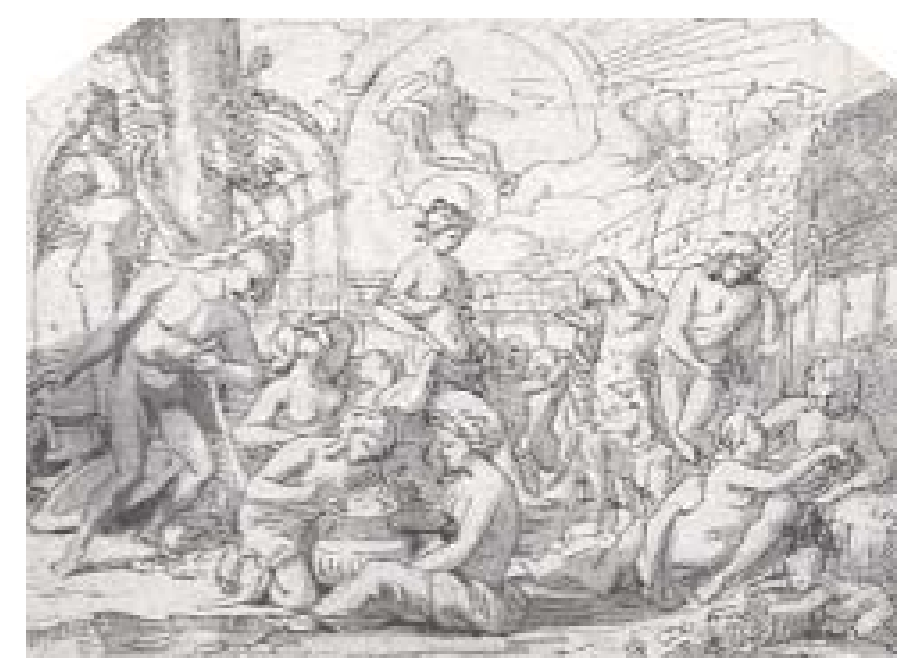

Figure 3. Nicholas Poussin, Kingdom of Flora, 1631, Windsor Castle.

\section{Linked Narratives}

In the Metamorphoses Ovid presents his stories through time: The poet starts with "The Creation" and then proceed through "The Four Ages" followed by the first deity-named story "Jove's Intervention"—all of this in Book I. Fifteen books are thus filled up with epic blank verse of some 100 stories that will mark the earthly landscape in terms of its humans, animals, flowers, and the like.

With each story Ovid introduces new characters who add to the narrative of human evolution so the reader gets a sense of what can happen to god and mortal alike as the drama plays out in the ancient world. Most characters and their circumstance appear only once but the Olympian gods and goddesses appear over and over helping or meddling in the affairs of the earthy mortals. Many of the narratives evoke conflict and can be analyzed as having a beginning (lead-in), middle (climax) and end (resolution), but the poet does not always offer his tales in the chronological sequence of the story (see Table 1).

Table 1

Flowers and Plants of Changing Forms in Ovid's Metamorphoses

\begin{tabular}{lllll}
\hline Book & Lines & Position & Story & Change \\
\hline I & $450-467$ & lead-in & Apollo \& Daphne & Daphne to laurel tree \\
III & $338-540$ & lead-in & Echo \& Narcissus & Narcissus to flower \\
IV & $55-171$ & lead-in & Pyramus \& Thisbe & couple to mulberry fruit \\
IV & $194-283$ & lead-in & Sun-god \& Leucothoe & Leucothoe to frankincense \\
IV & $283-388$ & lead-in & Salmacis & Clytie to flower; Crocus \& Smilax to flowers \\
\hline
\end{tabular}


(Table 1 continued)

\begin{tabular}{lllll}
\hline Book & Lines & Position & Story & Change \\
\hline VIII & $611-739$ & lead-in & Baucis \& Philemon & Baucis \& Philemon to oak \& linden \\
IX & $331-453$ & lead-in & Dryope & Lotis to flower; Dryope to tree \\
X & $1-121$ & lead-in & Orpheus \& Eurydice & boy to cypress; Cyparissus to cypress \\
X & $163-219$ & lead-in & Apollo \& Hyacinthus & Hyacinthus to red lily \\
X & $299-518$ & lead-in & Cinyras \& Myrrha & Myrrha to tree \\
X & $709-739$ & lead-in & Fate of Adonis & Adonis to anemone \\
XI & $1-84$ & lead-in & Death of Orpheus & Thracian women to oak forest \\
XI & $226-289$ & lead-in & Thetis & Thetis to tree \\
XIII & $305-398$ & lead-in & Ajax \& Ulysses & Ajax to crimson flower \\
XV & $501-563$ & climax & Hippolytus & spear to tree \\
\hline
\end{tabular}

In the Book I story of Lycaon the resolution comes first: The story is about a king who threatened the heavens and we read that the sinner "has been punished" for his plotting. The poet then goes on to tell of the horrific deeds of the tyrant, which included murder and the serving of human flesh to disguised Jove. The Olympian god then destroyed the evil monarch by crashing a lightning bolt into his house sending Lycaon fleeing to the fields where his robes turned to "shaggy hair" (of the wolf):

Yet he is still Lycaon, the same grayness,

The same fierce face, the same red eyes, a picture

Of bestial savagery. (Ovid, 1955, p. 10)

Ovid engages the reader, by not saying the name of the animal into which Lycaon changed, but mentions only the coloring and features so distinctly that we know who is chasing the sheep. Having the resolution come first in the story sets up clear guilt of the mortal — the verdict is in and Ovid only offers evidence after the initial statement by Jove.

For some narratives Ovid relays the climax in the first lines of the story. In the Book II story of Actaeon we follow one of the grandsons of Cadmus from the previous story. The Actaeon narrative is another of the poet's mixing of gods and mortals with dire consequences recorded in metamorphoses. After the brief introduction Ovid goes immediately to the climax of the story:

\footnotetext{
On his forehead

Horns sprouted, and his hound-dogs came to drink

The blood of their young master. (Ovid, 1955, p. 61)
}

From here the incident of the hunter coming on the sacred grove of Diana and her punishment of the innocent Actaeon, by turning him into a stag, explains the change of form. The change brings on the dogs that do not recognize their master transformed into a stag and rip him to pieces. The hunter becomes the hunted and Diana has her revenge against the one who accidentally came upon her bathing pool. As usual in these transformations, the poet identifies the changes one by one: The horns sprout, the neck elongates, ears become pointed, arms become legs and the skin a "dabbled hide". Having the climax of the story come first engages the reader to want to read onto learn what might cause such wrath to come to the unsuspecting hunter.

The presentation of linked events found a pictorial format in the very old continuous narrative, which Poussin used in his Midas and Bacchus, c. 1630 (see Figure 4). In this painting the main group of figures reveals Midas asking for the golden touch before a rich landscape illuminated through masses of cloud. In the 
middle distance Midas appears again below a river god which, provides the source for cleansing of the now curse of golden touch - the river Pactolus. It was common for renaissance artists to use continuous narratives in religious scenes and Poussin relied on it on occasion for some paintings and drawings. However, most of the French painter's oils are laid out in the single image format where one part of the story is depicted (maintaining the unity of time and place) while, other parts of the narrative might be referenced by using such devices as allegory. Poussin would have readily seen this approach in the mythological works of Titian such as Diana and Callisto, c. 1559 (which Walter Friedlaender has referenced for the gesture of Bacchus, reversed, in the Munich picture). ${ }^{5}$

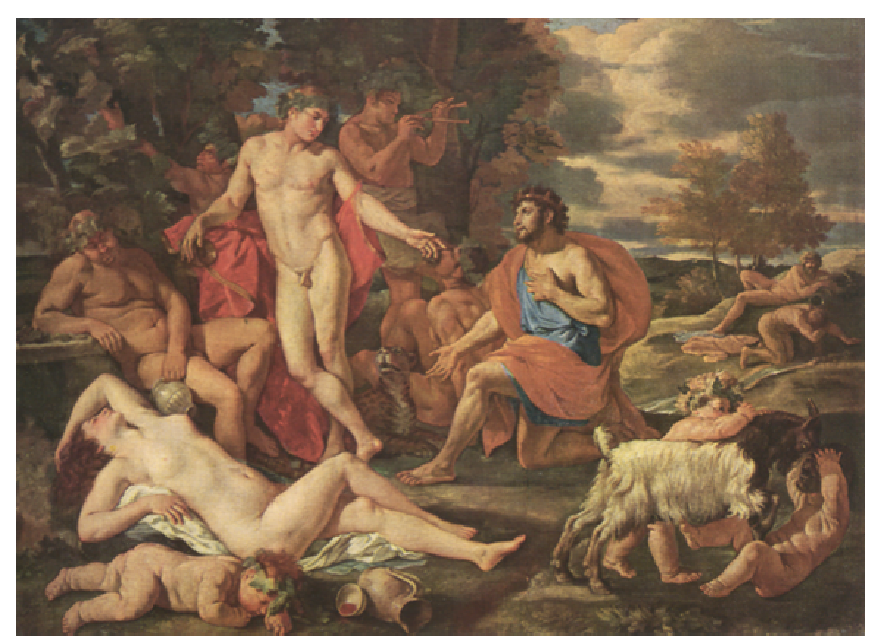

Figure 4. Nicholas Poussin, Midas and Bacchus, c. 1630, Pinakothek, Munich.

Most of the stories in the Metamorphoses are structured with a long lead-in that fills out the time and place of the narratives. This is skillfully constructed in the Book III story of Echo and Narcissus. Ovid has Tiresias, who had been granted the gift of prediction to comment if the boy Narcissus would have a long life: "Yes, if he never knows himself” (Ovid, 1955, p. 68) came the reply. The curious prediction set, the poet skillfully takes the reader through the short life of the tragic story of self-love and flower metamorphoses. The tone is elegiac as both genders sought the love of the teenager whose pride could not be penetrated and one who loved him, Echo, pines away to nothing.

Poussin was able to suggest this story in a single image painting Echo and Narcissus (1630) (see Figure 5) where the nymph fixes to a rock-face above an expired Narcissus where white flowers with a yellow center grow. A story within a story accounted for the strange speaking pattern of Echo, who acted as Jove's sentry, and was punished by Juno to only repeat the last words she heard spoken. As Echo came to pursue Narcissus, it is followed that she should be included as the scorned woman in the tale of male self-love allowing the painter to construct a unified composition of the failed affair. Cupid, who holds a love torch, makes the scene more poignant as he looks out of the picture seeking his next mission of love (resolution); this device simulated Ovid's method of introducing a subsequent story from the previous chapter. ${ }^{6}$

\footnotetext{
${ }^{5}$ Costello, p. 283. In 1630, Stefano Roccatagliata testifying at the Valguarnera trial stated that he owned a large painting representing the story of Bacchus and King Midas. The index of the Vulguarnera trial lists two "Midas” paintings.

${ }^{6}$ Ovid uses the device of linking stories in the Fasti: February begins with Janus (January) ending and the new month introduced. February ends in a harbor with an invitation to "sail in different waters" for the next month March. See pp. 19 and 40.
} 


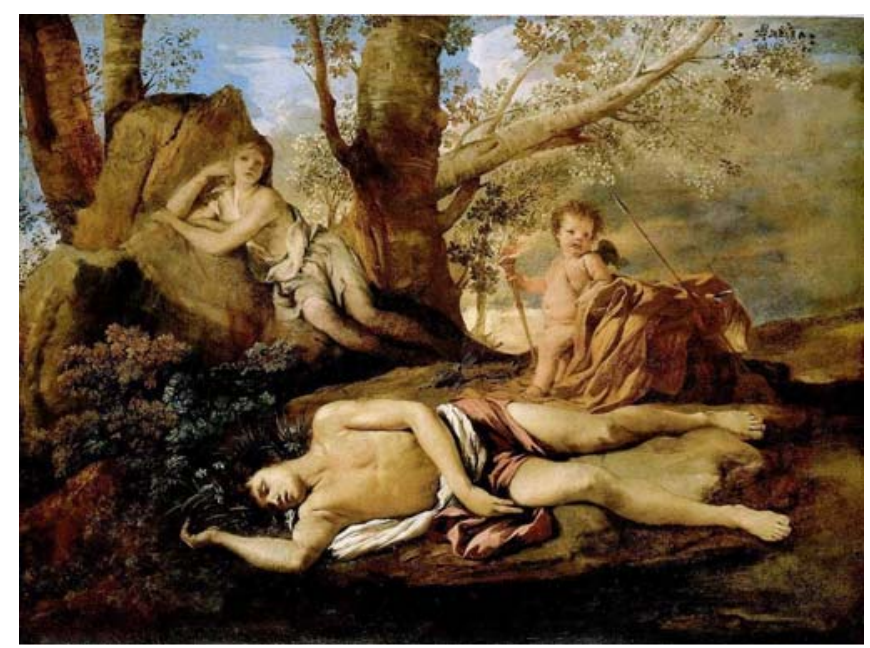

Figure 5. Nicolas Poussin, Narcissus and Echo, c. 1629-30, Louvre, Paris.

One major difference between Poussin and Ovid's approach to the narrative has to do with the observation of violence in the stories. While the painter shows Ajax falling on a sword, the effect is diminished by having the hero posed like a statue that supersedes the detail of the violent act. Ovid readily allows the violence to take over his scenes as in the stories of stabbed centaurs:

\footnotetext{
He stabbed him in the belly, so he jumped forward

Trailing his guts along the ground, and trod them

And burst them as he trod on them, and got tangled

In what was left, and fell with empty belly. (Ovid, 1955, p. 297)
}

How different these violent descriptions affect the viewer-reader: Poussin's stabbing remains a scene through time as an eternal pose and therefore has less effect on our sensations. Ovid's account is immediate and tactile as the guts are burst from the centaurs that walk over their own intestines. The poet makes the reader face violence and the seamy consequence of it. Poussin does not paint figures in excessive violence or in mid-metamorphoses, his figures are always intact: Ajax's body is noble and complete and his blood has already become the tall flower of his destiny. In this style the artist has completely shaken off Parisian mannerism where opportunities for strangeness of form and design are eschewed for the familiarity of tradition.

\section{Collective Narrative}

Ovid showed inventiveness in his collection of stories in the Metamorphoses to detail information about the many stories of change. In Book VI we read of the tale of the transformation of the "Maeonian girl" Arachne who was changed in to a spider. Arachne, who excelled at weaving, drew the envy of Minerva who challenged the artisan to a contest as to who could make the best weaving. Minerva's weaving proved a collage of portraits set before a landscape with miniature scenes of antique competition at the corners:

Minerva showed the hill of Mars in Athens

And that old conflict over the name of the land.

There sat the twelve great gods of high Heaven,

On lofty thrones in majesty, and Jove

Presiding above the well-known faces. 
From this introduction the principals are described with their attributes: "Neptune, smiting with his trident" and Minerva with the "aegis for her breastplate" and in the corners the stories of danger loom as warnings for the mortal weaver:

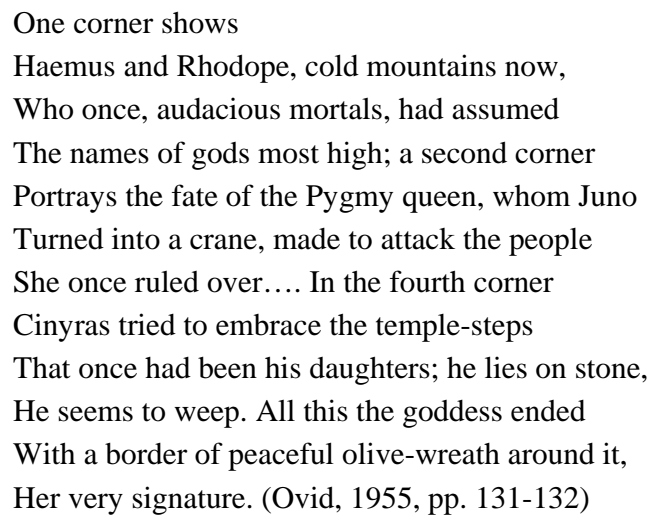

The image description set, not only the figures and place, but collaged stories of royal retaliation to flesh out Minerva's message of the power of the gods and goddesses and the dangers of bringing their displeasures. A similar method of multiple story presentation would be introduced by the painter of Ovid's mythologies.

Poussin's idea for the Kingdom of Flora (see Figure 2) was to take individual stories of figures transforming into flowers and put them together in a single picture. The figures easily assume the landscape. They do not look fractured (as in a modern collage), but bath in the same even light on the turf of the garden. Yet, the figures remain self-contained; the nymph opposite Narcissus does not acknowledge the violent suicide of Ajax before her and Clytie is the only one to gaze up to her beloved Apollo, the rest of the garden experiences the god as mid-day sunlight. It is only after we read their attributes, their postures that we realize that they are from disparate stories connected by the eternal regeneration of the garden. The painting brings these people together as a collection of stories that operates as a unit-a collective narrative.

The artist organized the composition to accommodate the figures by presenting them across the picture in two rows. To enable the flat effect of the garden setting Poussin has the figures sit low in the painting framed by the trellis and distant mountains. As Konrad Oberhuber points out, the artist lowers the horizon line "that allows for the shallow grouping... figures breathe and move in space with graceful clarity to which the light, spring like colors contribute” (Oberhuber, 1988, p. 247). The color scheme is regal in its combination of gold and blue set against earth tones. Draperies from Apollo to Clytie and Hyacinthus form a triangle of yellow-gold against the deep blue robes of Adonis and Echo. ${ }^{7}$ This theme is again picked up in the distant mountains set blue-violet against a yellow-orange sky. Patches of flowers add to the gay display below garlands of greenery and potted plants placed on a ledge beyond the herm of Priapus. The draperies are especially attractive as they convey splashes of color fulfilling Flora's mission to replace the "monochrome" of the earth with colored flowers (Ovid, 2013, p. 92). Here Poussin recalls Raphael's clear use of color over the more tonal approach he had used in the Triumph of Flora. The painting shows the artist's skill of invention to use color in a decorative manner over the collection of narrative figures recalling the many-storied approach used by Ovid.

However, Poussin's vision of Flora's realm showed an expression that was cleansed to meet a moral

\footnotetext{
${ }^{7}$ Blunt does not mention color in his description of the painting but thought the "linear harmony of the design" was formed by balancing diagonals, p. 106.
} 
imperative that avoided a lurid and suggestive approach that was readily available in the antique literature. Flora's future husband had raped her before she becomes a contented wife. In the Fasti Ovid tells us that the goddess describes herself "as a nymph of the happy field where once, you hear, fortunate men had business" (Ovid, 2013, p. 91). The sexual allusion of the poet is clear-this is not a green field of May (Flora's month) where men enjoy the landscape for its verdant pleasures but a reference to carnal pleasures with the nymph. The painter makes no reference to these activities in his oil but has her now with her chitin pulled up over her breasts (a drawing had her semi-nude, see Figure 3$)^{8}$ and only a partially revealing thigh. Flora has become respectable and her garden makes no allusion to risqué language of the poet, but reveals a wholesome affinity to the goddess as revealed in Titian's "portrait” Flora from c. 1520 (see Figure 6) where the goddess holds the flowers of spring.

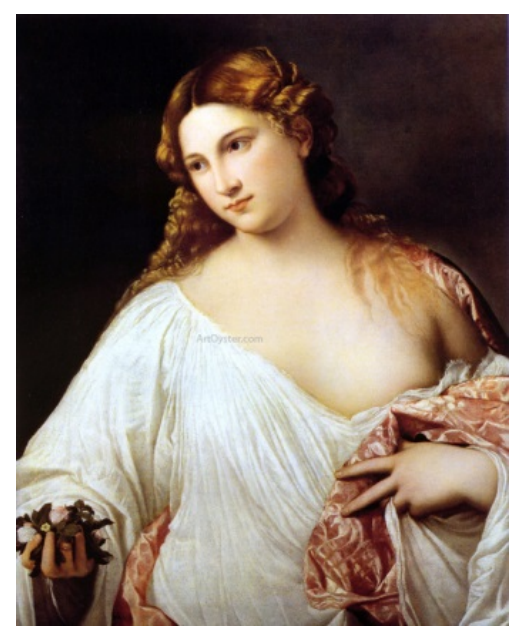

Figure 6. Titian, Flora, c. 1520, Galleria degli Uffizi.

There are times when Ovid has no need of innuendo and makes direct reference to gods and their interaction with mortals. In book ten of the Metamorphoses he writes:

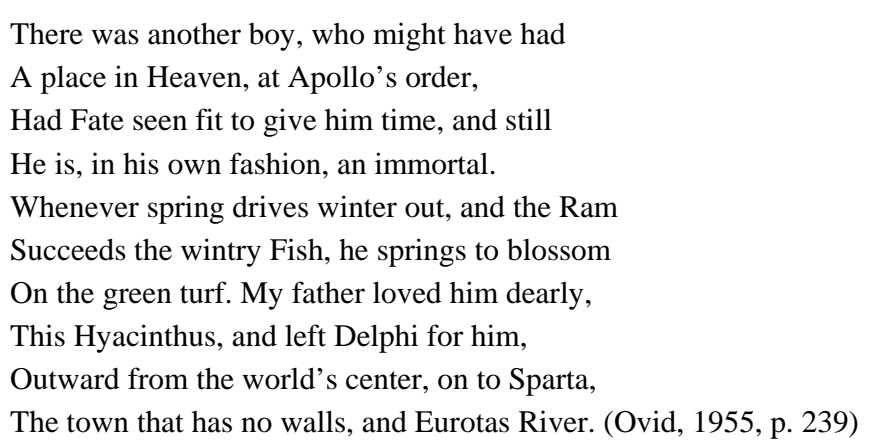

This passage, which leads to a description of the death of the youth from Sparta while playing discus, describes male friendships where bodies "rubbed with oil” play out Apollo's fire of love. It would be quite a leap to see a homosexual relationship in the Realm of Flora but the stories make it clear that the sun god took on male lovers of more than a passing fancy.

\footnotetext{
${ }^{8}$ Denis Mahon challenged Blunt's first date for the Dresden Flora at 1637-38 and suggested it should be placed at c. 1631 (Valguarnera visited the artist's studio in the fall of 1630) and places the Windsor drawing around this time. See "Poussin's Early Development: an Alternative Hypothesis”, The Burlington Magazine, Vol. 102, No. 688 (July, 1960), pp. 288-327.
} 
Another love in the garden was the affair between Venus and Adonis. In the painting the spear-holding hunter examines his gored leg from which the purple flowers bleed. This resolution to the story of accidental love makes no reference to the romance that Ovid described: Venus' breast grazed by Cupid's arrow in a kiss causes her to stay away from her places, Cythera, Paphos, Cnidos and even Heaven, for "Adonis is better than Heaven" (Ovid, 1955, p. 251). The goddess is taken by Adonis' beauty and follows him in the hunt with "robes-tucked up" and warns against hunting the bold creatures. And then she lays the hunter on her breast (as a pillow) under the poplars where she gave him kisses. At Adonis' death she laments the early passing of her lover and the exposure of fornication outside of her marriage to Vulcan will have to wait for another time (with the god named for the month of March).

Poussin can only make reference to all this illicit love of Venus by having putti dance in a ring of uninhibited joy in Flora's garden. Here love is suggested more than apparent as we watch Crocus transform into a fair maiden (not apparent in the drawing, see Figure 3) and we are left to ponder a Sappho-kind-of-love with Smilax in this exchange between the hopeless couple. ${ }^{9}$ Everywhere there is love implied, heroes honored and beauty expounded as the sun nourishes over sweet sentiment while Priapis protects the garden, his sighs for Lotis not evident (Ovid, 2013, p. 11). The Kingdom of Flora remains an elegant picture where color decorates perfect forms in an idyllic setting that transports the viewer to an imaginary place where spring refreshes eternally.

\section{Conclusion}

Ovid can be described as a romantic for his macabre approach to ancient stories of love, lust and horrific violence in the antique world. His descriptions range from poetic accounts of figures "shape-shifting" into creatures to godly favorites transforming into flowers. The poet's language can be raw and direct-the prose of blood and guts and the realism of that genre. Poussin, on the other hand, wanted no part of this view of the ancients, but sought to depict a world of beauty and perfection. As a classicist Poussin operated under the principle that knows he has time on his side. He knows that the spring season will bring new growth and heal old wounds. He knows the most horrific deeds will be forgotten and that a positive outlook will return to favor-a worldview that was by nature optimistic.

Yet, it would be wrong to suggest that Poussin was rigid and not open to new ideas or alternative ways to illustrate mythological narratives. Pictorial variety caused him to try and invent composition and color ideas dependent on the needs of the picture. In this Poussin can be described as a classicist who operated under a system of values that held up the natural temperament of the artist's need to create fresh expressions. For this he had only to follow the model of the poet who cast his tales of love lost in various temporal machinations and image presentations - all of which opened up possible pictorial compositions for the painter to make the stories of change engaging.

\section{References}

Bellori, G. P. (2010). The lives of the modern painters, sculptors and architects. Cambridge: Cambridge University Press. Blunt, A. (1967). Nicholas Poussin. New York: Pantheon.

Costello, J. (1950). The twelve pictures 'ordered by Velasquez' and the trial of Valguarnera. Journal of the Warburg and Courtauld Institutes, XIII, 237-284.

Friedlaender, W. (1960) Nicholas Poussin. New York: Abrams.

\footnotetext{
${ }^{9}$ Sappho of Lesbos.
} 
Mahon, D. (1960). Poussin’s early development: An alternative hypothesis. The Burlington Magazine, 102(688), $288-327$. Oberhuber, K. (1988). Poussin: The early years in Rome. New York: Hudson Hills Press.

Ovid. (1955). Metamorphoses (R. Humphries trans.). Bloomington: Indiana University Press.

Ovid. (2013). Fasti (A. P. Wiseman trans.). Oxford: Oxford University Press.

The Flower Expert. (2014). Hyacinth. Retrieved from http://www.theflowerexpert.com

Wright, C. (1984). Poussin's paintings: A catalogue raisonne. New York: Alpine Fine Arts Collection. 